thick skin of a dinosaur can be simulated by bouncing light off the exterior. But human skin is softer and more translucent, so light enters and bounces around dozens of times before exiting. These properties, which are easily observed by putting your hand in front of a bright light, are crucial to a realistic portrayal.

Realistic animation also depends on knowledge of how skin, muscles and hair move independently of a charac-

"Realistic
animation
depends on
knowledge
of how slin,
muscles and
hair move
independently
of acharacter's
performance."
ter's performance. These secondary motions are achieved through intensive simulations that compute all of the mass, dynamics, tensions and interaction of each part of the body as a character moves.

The simulations help to create the complex visual cues that the human brain processes when taking in an image. They also ensure that the physiology of creatures (real or fantastical) has a ground truth and is believable. Combining this new level of detail with motion-captured performances of talented actors has enabled computer-animated characters to become lead actors.

Rupert Wyatt's 2011 Rise of the Planet of the Apes featured a chimpanzee named Caesar who was not just the protagonist; he was the emotional centre of the film. This entirely digital character is a great example of how the advances in animation work together, from muscle simulation, fur and realistic lighting, to motion-captured body and facial performance.

The following year saw all of these developments come full circle when we were able to once again present Gollum in Peter Jackson's The Hobbit: An Unexpected Journey. This new Gollum benefited from a much more detailed digital model, new subsurface scattering techniques and all of the advances we have made in the past ten years. If you watch closely, you will see the muscles moving under his skin and the light refracting in his eyes. And you will get a glimpse of the worlds we can create from the mix of all this art and science.

Joe Letteri is senior visual effects supervisor at Weta Digital in Wellington, New Zealand. He has received four Academy Awards for Visual Effects and the Academy's Technical Achievement Award for co-developing the subsurface-scattering technique that brought Gollum to life. His latest film is The Hobbit: The Desolation of Smaug, on general release this week. e-mail:digital@wetafx.co.nz

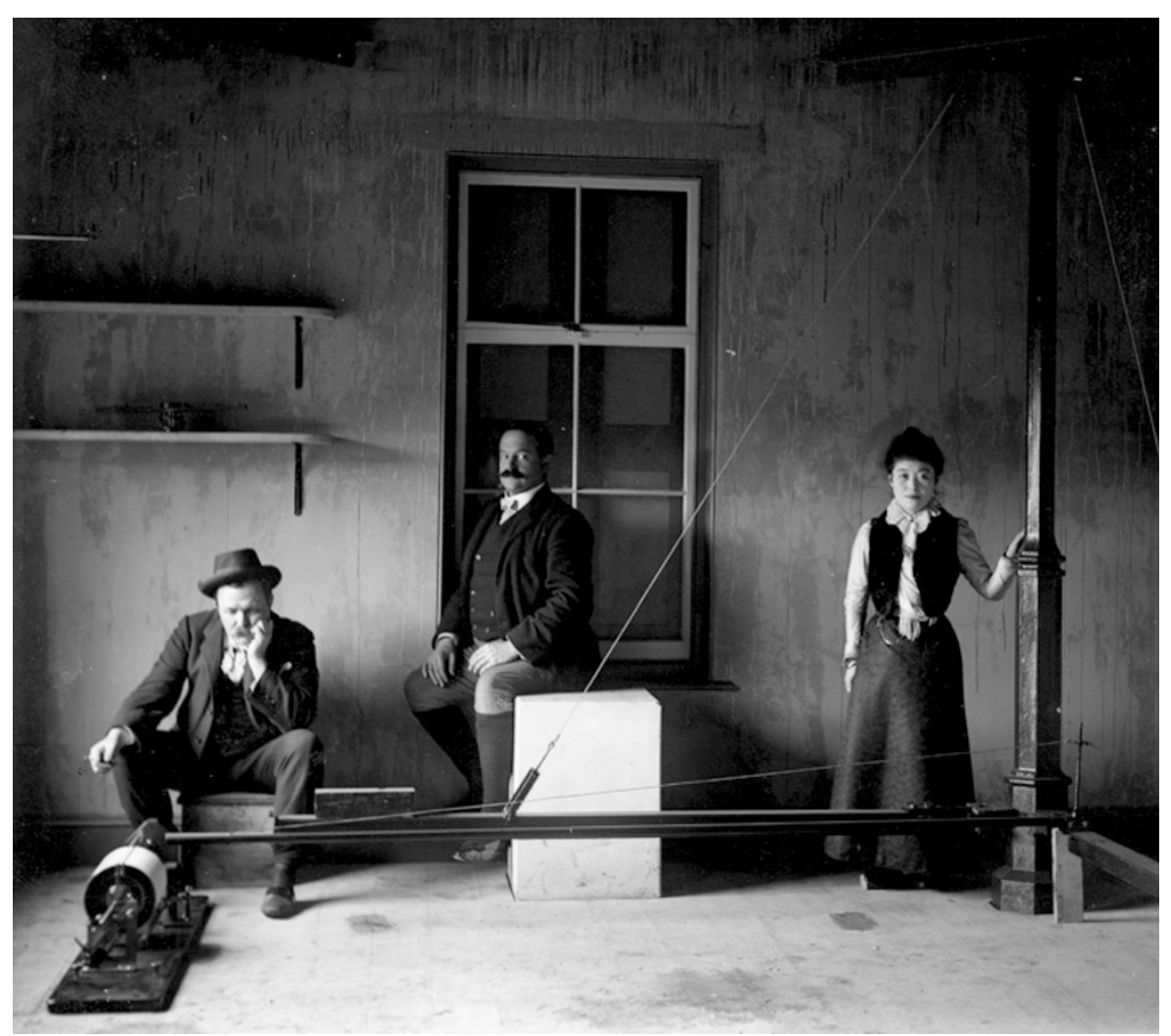

John Milne (left) with his wife Tone, seismologist Boris Galitzin and a lamp-post seismometer in 1910.

GEOLOGY

\title{
The maverick founder of modern seismology
}

\section{George Helffrich relishes a film on John Milne, whose work in Japan put earthquake science on the map.}

$\mathrm{W}$

hat European other than Marco Polo, on taking up a job in the Far East, would travel overland? John Milne. No posh Brit he: the Victorian geologist reached Japan mainly by train, foot and pack animal, ostensibly to avoid seasickness. As I write this, flying to Japan across eastern Siberia, I am amazed. I detect a whiff of the iconoclast.

Milne's motivation for that epic journey was an invitation from Japanese officials of the Meiji era (1868-1912) to establish an Imperial College of Engineering in Tokyo, and to transfer Western knowledge to Japan. After arriving in 1875 to teach geology and mining, he became aware of the frequency of earthquakes and their damaging effects. Building designs transplanted from the West performed particularly poorly. By 1878 , Milne determined that to study earthquake damage properly, he needed to quantify seismicity - or the frequency and strength of earthquakes instrumentally. His goal became to build a standard seismometer and establish a seismic network across Japan.

\author{
The Man Who \\ Mapped the \\ Shaking Earth \\ DIRECTOR: WILLIAM \\ TWYCROSS \\ 2013.
}

That plan was the inception of modern global seismology.

To mark this year's centenary of Milne's death, his great-nephew William Twycross made a documentary, The Man Who Mapped the Shaking Earth. Shown in July at the assembly of the International Union of Geodesy and Geophysics in Gothenburg, Sweden, the film immerses us in Milne's life in science, including his photographs and sketches. Often shooting on location, Twycross and his film crew trace Milne's travels in Iceland, the Canadian island of Newfoundland, Britain, Russia and the United States, as well as to and in Japan. Twycross imposes a fine narrative continuity 
despite the logistical complexities.

Milne's astonishing saga began at King's College London, where he studied science. His published account of a study trip to Iceland in 1871, when he was 21, showed him to be a competent diarist and illustrator, and won him a scholarship to the Royal School of Mines (now part of Imperial College London). He suspended his studies there to complete a commercial geological survey of Newfoundland, where he incidentally studied the recently extinct great auk. On a Royal Geographical Society expedition to Egypt's Sinai peninsula in 1874 , he marshalled his new skills in geology and illustration to create geographical cross-sections of the region work that paved the way for his post in Japan.

Once there, he published his trans-Asian travelogue in the Transactions of the Asiatic Society of Japan, and climbed, studied, sketched and even discovered some volcanoes, one of which is now named Milne. He made archaeological and anthropological studies of the indigenous Ainu culture and people of the northern Japanese islands, and met his wife-to-be, Tone Horikawa. After the Tokyo-Yokohama earthquake of 1880 , he established the Seismological Society of Japan and its journal - both world firsts. The Royal Society of London elected him a fellow in 1887.

In 1895, Milne left Japan with Tone for the Isle of Wight, off the south coast of Britain, building a seismological observatory there and working towards the standardization of instruments such as the horizontal pendulum seismograph to record earthquakes worldwide. The captaincy of the island's Newport Golf Club and membership of the local photography and chess clubs occupied his idle moments. By 1903 he had set up the world's first global seismic network, with 40 stations encompassing every continent reporting to his observatory, Shide Hill House. He also published the periodic Shide Circular Reports on Earthquakes from 1900 to 1912 , a precursor to the seismological catalogues accumulated by national agencies around the world. His obituary (see Nature 91, 587-588; 1913) hints at some resistance to coordinating his network with the International Seismological Association - not surprising, given his personal achievement.

The Man Who Mapped the Shaking Earth paints an unembellished portrait of a dedicated visionary. Milne wove the threads of seismic instrumentation and observation into a tool to develop fundamental knowledge of how Earth works. What could be more compelling or inspiring to a student of seismology or the history of science? -

George Helffrich is professor of seismology at the University of Bristol School of Earth

Sciences, UK.

e-mail: george.helffrich@bristol.ac.uk

\section{Books in brief}

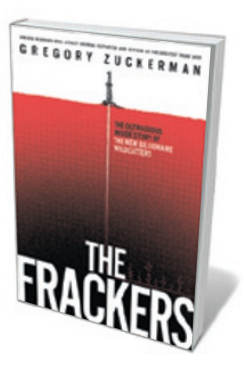

The Frackers: The Outrageous Inside Story of the New Billionaire Wildcatters

Gregory Zuckerman PORTFOLIO (2013)

Investigative journalist Gregory Zuckerman maps the landscape of the new US oil boom, currently producing 7.5 million barrels of crude a day. Focusing on the widespread technique of fracking - hydraulic fracturing of deep shale deposits for oil and gas Zuckerman plaits portraits of the 'wildcatters' who champion the practice into a pacy chronicle of the boom. His take on the issues is balanced, but this is not the place to find a lengthy analysis of the potential impacts of fracking on environmental systems.

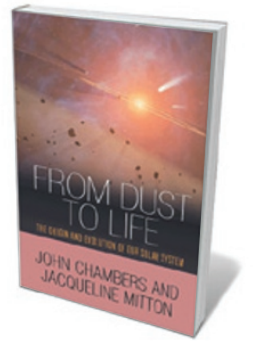

From Dust to Life: The Origin and Evolution of Our Solar System John Chambers and Jacqueline Mitton PRINCETON UNIVERSITY PRESS (2013)

This research round-up of how our "cosmic neighbourhood" evolved is a stellar read. Planetary scientist John Chambers and science writer Jacqueline Mitton shuttle the reader through the big discoveries - from heliocentricity to findings in the past 50 years, as missions, telescopes and light detectors probe deeper. Lingering mysteries such as early planet formation are laid out, along with details on current missions such as New Horizons, headed for the Kuiper belt of asteroids and set to encounter Pluto in July 2015.

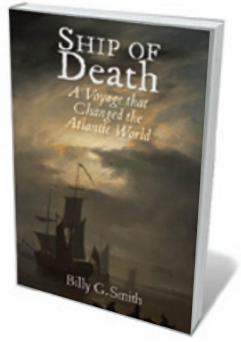

Ship of Death: A Voyage That Changed the Atlantic World Billy G. Smith YALE UNIVERSITY PRESS (2013)

One of the strangest tales in the annals of medicine must be the voyage of the Hankey. Historian Billy G. Smith has resurrected the long-buried history of the British abolitionists who set off in the ship to found a slavery-free West African colony in the late eighteenth century. They failed - then inadvertently wreaked viral havoc as the Hankey left Africa riddled with mosquitoes carrying yellow fever. Stopping at various Atlantic ports, the ship contributed to a pandemic that killed tens of thousands. Packed with fascinating nuggets - such as the part played by that deadly cargo in the liberation of Haiti.

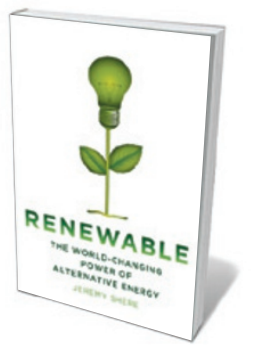

Renewable: The World-Changing Power of Alternative Energy Jeremy Shere ST MARTIN'S PRESS (2013)

Renewable energy is a tortuous, fast-moving field, and in this contribution to the shelves of books on it, science journalist Jeremy Shere offers a welcome pragmatism. Organizing his survey by power source, from plants to water, he examines state-of-the-art technologies and their surprising histories. We visit researchers who probe cellulosic energy crops, algal oil, nanotechnology-enhanced solar cells and much more. At a time when countries including the United States and China are investing heavily in renewables, Shere notes that combining alternative-energy choices strategically is key.

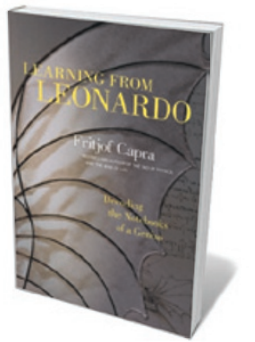

Learning from Leonardo: Decoding the Notebooks of a Genius Fritjof Capra BERRETT-KOEHLER PUBLISHERS (2013)

Was Leonardo da Vinci essentially a systems theorist? So argues physicist Fritjof Capra. His compelling exploration of Leonardo's breakthroughs in areas such as fluid dynamics reveals an intellectually fearless mind constantly seeking patterns, relationships and context. Leonardo could have changed the course of science through discoveries such as how the heart functions; but he never published, and the credit went to others. Barbara Kiser 